\title{
The Role of Calf Serum in the Growth of Chlamydia trachomatis in McCoy Cell Cultures
}

\author{
By PETER KARAYIANNIS AND DEREK HOBSON* \\ Department of Medical Microbiology, The Medical School, University of Liverpool, \\ Liverpool L69 3BX
}

(Received 11 February 1980; revised 10 June 1980)

\begin{abstract}
Chlamydia trachomatis is normally grown in McCoy monolayer coverslip cultures using partially defined media containing foetal calf serum at concentrations up to $10 \%(\mathrm{v} / \mathrm{v})$. Omission of the serum decreased the number of inclusions produced by infecting the McCoy cells with a standard inoculum of a genital strain of $C$. trachomatis. Substitution of the foetal calf serum with a macromolecular fraction from the serum or with a mixture of sodium oleate, bovine serum albumin fraction $\mathrm{V}$ and fetuin maintained the inclusion count, but substitution with serum filtrate, containing the amino acids and other low molecular weight components, decreased the inclusion count of $C$. trachomatis. The role of calf serum and the need for a fully defined medium excluding serum for studying the growth of $C$. trachomatis in tissue culture are discussed.
\end{abstract}

\section{INTRODUCTION}

The isolation of Chlamydia trachomatis from secretions is the only satisfactory way to diagnose human infections with this agent, which is a common cause of sexually transmitted disease and of severe ophthalmic infections (Hobson, 1977a). Chlamydia trachomatis can be cultivated in mammalian tissue cultures, and the McCoy line of mouse fibroblasts (Gordon \& Quan, 1965) has been used most widely. However, there is as yet no general agreement on the optimum cultural conditions for diagnostic purposes or, indeed, for basic biological studies on this organism (Hobson, 1977b). Some work in this direction has been done with certain laboratory strains of $C$. psittaci (Bader \& Morgan, 1958) but the biology of this species differs significantly from that of $C$. trachomatis (Becker, 1978) and thus this work may not be relevant. The degree of growth of $C$. trachomatis in McCoy cells varies with the type of tissue culture medium in which the McCoy cells are grown (Johnson \& Hobson, 1976; Rota \& Nichols, 1973) and with the degree of replication of such cells (Gordon et al., 1972; Wentworth \& Alexander, 1974; Sompolinsky \& Richmond, 1974; Ripa \& Mårdh, 1977; Bushell \& Hobson, 1978). This suggests that there may be competition between host cell and parasite for essential metabolites in the medium, as is the case with $C$. psittaci (Alexander, 1968; Hatch, 1975). There is no guarantee that currently used tissue culture media are optimal for the growth of either McCoy cells or of $C$. trachomatis. Their formulation thus requires re-evaluation.

At present, by convention, 5 to $10 \%(\mathrm{v} / \mathrm{v})$ foetal calf serum is added to the basic chemical medium used throughout the period of chlamydial infection of tissue culture cells. The need for calf serum is unknown. It may provide a source of unbound nutrient factors such as amino acids, vitamins or hormones which may be essential metabolites for McCoy cells, chlamydiae or both, but which cannot be supplied by commercial tissue culture media alone. Alternatively the role of calf serum may be physical rather than chemical in nature, its macromolecular components acting, for example, as a protective agent or physiological buffer, or as an aid to host cell adhesion or flattening, or as a means of facilitating pinocytotic 
and other transport activities of the cell membrane (Taylor, 1974). However, the use of calf serum has many disadvantages. Different batches, or a single batch after different periods or conditions of storage, may vary in composition (Bittles, 1974) and in their growth-promoting effect on tissue culture cells. Adventitious contamination by bacteria, fungi, mycoplasma, bacteriophage or blood cells, or by antigens or metabolic by-products derived from these contaminants, is implicit in the method of collecting sera under industrial conditions (Taylor, 1974). The complex and variable constitution of serum impedes assessment of the role of the many individual amino acids, vitamins or hormones present in the defined basic fraction of the medium, because such components are also likely to be present in unknown amounts in the serum itself. The tendency of serum proteins to bind small molecular constituents and, particularly, antibiotics is a disadvantage in investigating promotion or inhibition of chlamydial growth by various agents added to the medium. The high viscosity of serum, together with the possibility that certain of its macromolecular components may bind to the tissue culture cell surface, is a potential disadvantage in the study of centrifuge-assisted adsorption of chlamydial particles and of possible specific receptor sites for this agent. The possibility of bovine serum containing specific antibodies against at least the group antigen of chlamydiae can be minimized by using only foetal serum, but this is becoming increasingly difficult and expensive to obtain. Thus, there would be advantages in removing calf serum, or all unnecessary components of serum, from tissue culture media when studying the biological characteristics of chlamydiae growing within mammalian cells. For example, Morrison \& Jenkin (1972) found that the lipid metabolism of $C$. psittaci in suspended L-cell cultures could not be assessed in serum-containing media. In their short-term metabolic experiments serum could be replaced by bovine serum albumin plus sodium oleate. However, the ability of these or other serum substitutes to permit infective yields of $C$. trachomatis in tissue culture monolayers as great as those in monolayers maintained in foetal calf serum has not been explored. It seems surprising that the possible role of fetuin in this respect has not been investigated since this substance, an $\alpha$-foeto-protein, is a major component of foetal sera and is well-known to be important in maintaining adhesion and allowing flattening and spreading of mammalian cells on to glass in the development of tissue cultures (Fisher et al., 1958). Furthermore, the need for calf serum in conventional replicating tissue culture used hitherto may differ from that in tissue culture treated with anti-replicative agents such as cycloheximide (Alexander, 1968) or iododeoxyuridine (Wentworth \& Alexander, 1974), both of which are now widely used to increase the susceptibility of tissue cultures to chlamydial infection.

The present paper explores the role of calf serum, and the possibility of withdrawing serum completely, or replacing it with specific substitutes of known concentration and known function, as a first step in the development of a completely synthetic and chemically defined medium for the isolation and propagation of C. trachomatis in cycloheximide-treated McCoy tissue cultures.

\section{METHODS}

Abbreviation. MCC, McCoy monolayer coverslip cultures.

Strain of Chlamydia trachomatis. The single pool of cells (TC 1370) of C. trachomatis strain BK, which was used throughout these experiments, was the sixth passage in McCoy cells of a strain isolated from the genital tract of a patient in the Liverpool Royal Infirmary. Details of the preparation of high-titre pools of strain BK have been described by Bushell \& Hobson (1978). The pool of strain BK was stored in $0.2 \mathrm{ml}$ lots at $-70^{\circ} \mathrm{C}$ in ampoules which were thawed immediately before use but not re-frozen or re-used subsequently. Dilutions of the pool were made in Earle's balanced salt solution (Flow Laboratories). The titre of the undiluted pool of organisms (TC 1370) was $1.67 \times 10^{5}$ inclusion-forming units $\mathrm{ml}^{-1}$, estimated as described below by the inclusion count in MCC inoculated and incubated under standard conditions for $48 \mathrm{~h}$.

The serotype of strain BK was kindly determined as type D/E (typical of genital strains of C. trachomatis isolated in this country) by Dr J. Treharne, Institute of Ophthalmology, London.

Tissue culture procedures. The source of the McCoy cell line, methods for its propagation and the preparation 
of MCC, methods of infection with C. trachomatis, and fixation, Giemsa-staining and dark ground microscopic examination of MCC after infection have all been described in detail previously (Davies et al., 1978). In the present experiments, medium MB752/1 (Waymouth, 1959) was used throughout for growth and maintenance of the McCoy cells, because it was specifically designed to meet the nutritional requirements of the L-cell line of mouse fibroblasts, now known to be closely related to McCoy cells (Gordon et al., 1972). This medium was freshly made for each day's experiments from single master stocks of concentrated solutions of individual amino-acids, etc. according to the formulation and methods described by Waymouth (1959). It is referred to throughout as Liverpool-Waymouth medium to differentiate it from commercial MB752/1 medium.

McCoy monolayer coverslip cultures (MCC) were prepared by inoculating $1.5 \times 10^{5}$ McCoy cells, freshly obtained from stock cultures, into Liverpool-Waymouth medium plus $10 \%(\mathrm{v} / \mathrm{v})$ foetal calf serum and incubating for $24 \mathrm{~h}$ at $35^{\circ} \mathrm{C}$. By this time the coverslip supported approximately $3 \times 10^{5}$ cells in a confluent monolayer covering the whole coverslip area. Immediately before infection with $C$. trachomatis strain BK the growth medium was removed and monolayers were washed in Earle's balanced salt solution before adding various test media. A dilution of strain BK estimated to yield approximately 5000 inclusions per whole coverslip was then inoculated in a volume of $0.2 \mathrm{ml}$ into MCC already containing $1.0 \mathrm{ml}$ of appropriate medium. A low multiplicity of infection was chosen for inoculation of MCC in order to simplify assessment of the efficiency of plating and inspection of the size and quality of well-separated inclusions, as described previously (Johnson et al., 1977). Cycloheximide (made up in distilled water as a stock solution containing $1 \mathrm{mg} \mathrm{m}^{-1}$ and diluted in balanced salt solution) was added to

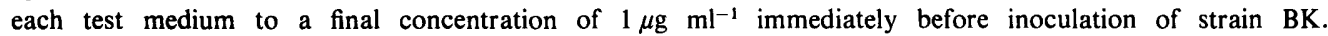
After centrifuge-assisted adsorption for $1 \mathrm{~h}$ at $33^{\circ} \mathrm{C}, \mathrm{MCC}$ were incubated for $48 \mathrm{~h}$ at $35^{\circ} \mathrm{C}$, fixed, Giemsa-stained and examined for chlamydial inclusions by dark ground microscopy. The variation in inclusion counts in replicate cultures were as previously assessed (Johnson \& Hobson, 1976), the $95 \%$ confidence limits being within $\pm 23.5 \%$ of the mean count. The number of replicate cultures used in each experiment ranged from three to twelve.

Further investigation of test media. In most experiments MCC were maintained in the same test medium throughout the whole $48 \mathrm{~h}$ incubation period after infection. However, in experiments to assess the effect of the test medium specifically on the adsorption phase of the infective cycle, the test media were removed immediately after the centrifugation period following infection of the MCC with strain BK and were replaced by the standard maintenance medium [Liverpool-Waymouth medium containing $10 \%(\mathrm{v} / \mathrm{v})$ foetal calf seruml. In other experiments, infected MCC were changed from this standard medium to various test media with or without serum or serum substitute, or from test media to the standard medium at various later times during the $48 \mathrm{~h}$ post-infection incubation period. Cycloheximide was added to each test medium.

In passage experiments to determine the infective yield of strain BK in MCC maintained in various media, randomly chosen MCC infected with strain BK were stained at $48 \mathrm{~h}$ or $72 \mathrm{~h}$ after infection to estimate the inclusion count. Other primary infected MCC were harvested at $72 \mathrm{~h}$, and the cells were disrupted ultrasonically into their tissue culture medium $(3 \times 15 \mathrm{~s}$ exposure in a Rapidis 150; Ultrasonics Ltd, Shipley). The resulting suspension was inoculated without further dilution into fresh MCC, maintained in Liverpool-Waymouth medium plus $10 \%(\mathrm{v} / \mathrm{v})$ foetal calf serum and treated with cycloheximide. The inclusion count was measured by staining the MCC after $48 \mathrm{~h}$ incubation to give an estimate of the infective yield of strain BK which had been produced in the primary MCC.

Fractionation of foetal calf serum. Whole foetal calf serum (batch $\mathrm{L}, 5 \mathrm{ml}$ ) was fractionated by ultrafiltration through a membrane with a molecular weight cut-off of 50000 (CF $50 \mathrm{~A}$; Amicon, High Wycombe, Bucks.), the process being accelerated by centrifuging at $750 \mathrm{~g}$ for $15 \mathrm{~min}$ at $4^{\circ} \mathrm{C}$. The macromolecular fraction retained by the membrane was made up to $5 \mathrm{ml}$ with Earle's balanced salt solution and the procedure was repeated. Both the macromolecular fraction and the filtrate were collected, made up to $5 \mathrm{ml}$ with Earle's balanced salt solution, sterilized by membrane filtration and stored at $-70^{\circ} \mathrm{C}$. Liverpool-Waymouth medium and Earle's balanced salt solution containing $10 \%(\mathrm{v} / \mathrm{v})$ of these serum fractions were compared with the media alone and with the media containing $10 \%(\mathrm{v} / \mathrm{v})$ whole serum for their ability to maintain MCC during infection with strain BK.

Serum substitutes. Bovine serum albumin fraction V, sodium oleate and fetuin were used alone or together in place of serum. Stock solutions were made up in distilled water (bovine serum albumin, $20 \mathrm{mg} \mathrm{ml}^{-1}$; sodium oleate, $1 \mathrm{mg} \mathrm{ml}^{-1}$; fetuin, $10 \mathrm{mg} \mathrm{ml}^{-1}$ ) and stored at $-20^{\circ} \mathrm{C}$. For use in test media for maintenance of $\mathrm{MCC}$ during infection with strain BK, these components were added to Liverpool-Waymouth medium to give final concentrations of, respectively, $2 \mathrm{mg} \mathrm{ml}^{-1}, 10 \mu \mathrm{g} \mathrm{ml}^{-1}$ and $1 \mathrm{mg} \mathrm{ml}^{-1}$.

Materials. A total of 12 samples of serum - one of 101 (batch $\mathrm{L}$ ) as a reference batch, produced by Flow Laboratories, and 11 others, of $500 \mathrm{ml}$ or more, produced by four other commercial suppliers - were obtained for examination. Each batch of serum was stored in $20 \mathrm{ml}$ lots at $-20^{\circ} \mathrm{C}$. Each sample was thawed and used within $1 \mathrm{~d}$; it was not re-frozen. Bovine serum albumin fraction $\mathrm{V}$ was obtained from Armour Pharmaceutical Co., sodium oleate and cycloheximide were obtained from $\mathrm{BDH}$, and fetuin ( $\alpha$-foeto-protein) was obtained as a freeze-dried preparation from Nutritional Biochemical Corp., Cleveland, Ohio, U.S.A. 
Table 1. Mean inclusion count of C. trachomatis strain BK in McCoy monolayer coverslip cultures maintained in Liverpool-Waymouth medium alone or supplemented with different concentrations of foetal calf serum

$\begin{gathered}\text { Foetal calf serum } \\ (\%, \mathrm{v} / \mathrm{v}) \\ 20 \\ 10 \\ 5 \\ 1 \\ 0 \cdot 5 \\ 0 \text { (control) }\end{gathered}$

No. of coverslips
examined
3
12
3
3
3
11

* Count for whole coverslip, $10 \mathrm{~mm}$ diam.

$\begin{array}{cc}\begin{array}{c}\text { Mean inclusion count } \\ 48 \text { h post-infection }\end{array} & \begin{array}{c}\text { Relative inclusion } \\ \text { count }\end{array} \\ 4148 & 3.05 \\ 4020 & 2.95 \\ 3184 & 2.34 \\ 2392 & 1.76 \\ 1598 & 1.18 \\ 1360 & 1.00\end{array}$

1.00

\section{RES ULTS}

\section{Effect of different concentrations of foetal calf serum}

In MCC maintained in Liverpool-Waymouth medium alone or with foetal calf serum (from 0.5 to $20 \%, \mathrm{v} / \mathrm{v}$ ), the McCoy cells appeared substantially unaltered over the $48 \mathrm{~h}$ incubation period, except for slight elongation in the absence of serum, with the appearance of a few spindle cells of fibroblastic morphology in the thinner parts of the monolayer. The number of inclusions varied directly with the concentration of serum added (Table 1). In the absence of serum, the count was reduced to one-third of the maximum. Moreover, with decreasing amounts of serum there was a progressive decrease in the mean size of the inclusions (from 18.2 to $11.0 \mu \mathrm{m}$ diam.) and in the density of array of elementary bodies within them. In all subsequent experiments, the growth of strain BK in media with $10 \%(\mathrm{v} / \mathrm{v})$ serum and in media without serum were used as standards for comparison.

\section{Effect of age of foetal calf serum}

Over 20 months use of serum (batch L) in two to three experiments per week, the inclusion counts per MCC ranged only between 4012 and 5072 (mean 4606) and there was no consistent downward trend of counts with time. Thus, under these conditions, the effect of serum on the growth of strain BK did not appear to change with age.

\section{Effect of different batches of foetal calf serum}

When MCC were maintained in Liverpool-Waymouth medium supplemented with $10 \%$ $(\mathrm{v} / \mathrm{v})$ serum from each of the 12 batches and subsequently infected, variations in the inclusion counts were minimal. The poorest batch of serum gave a count of 4771 per coverslip and the best gave a count of 8721 , representing $80 \%$ and $140 \%$, respectively, of the count (5967) in batch L. Moreover, the size of the inclusions and the density of array of elementary bodies in them showed no significant difference from batch to batch.

\section{Effect of serum alone and of media containing ultrafiltration fractions of foetal calf serum}

McCoy cells appeared normal when maintained either in Liverpool-Waymouth medium supplemented with whole serum or its ultrafiltration fractions (see Methods) or in Earle's balanced salt solution supplemented with whole serum or with the macromolecular fraction of serum. However, there was gross cell elongation when they were held in the salts solution with or without serum filtrate; without the serum filtrate some cells developed pyknotic nuclei.

Earle's balanced salt solution alone did not support the growth of strain BK, but when it was supplemented with $10 \%(\mathrm{v} / \mathrm{v})$ whole serum the inclusion count was as high as in Liverpool-Waymouth medium plus $10 \%(\mathrm{v} / \mathrm{v})$ whole serum and significantly higher than in Liverpool-Waymouth medium alone (Table 2); the inclusion size and quality were similar to those in Liverpool-Waymouth medium plus $10 \%(\mathrm{v} / \mathrm{v})$ whole serum. Inclusion counts in 
Table 2. Mean inclusion count of $C$. trachomatis strain BK in McCoy monolayer coverslip cultures maintained in either Liverpool-Waymouth medium or Earle's balanced salt solution both alone and supplemented with $10 \%(v / v)$ whole or fractionated foetal calf serum

\author{
Medium \\ Liverpool-Waymouth + whole serum \\ Liverpool-Waymouth alone \\ Balanced salt solution + whole serum \\ Balanced salt solution alone \\ Liverpool-Waymouth + serum macromolecular fraction \\ Liverpool-Waymouth + serum filtrate \\ Balanced salt solution + serum macromolecular fraction \\ Balanced salt solution + serum filtrate
}

\begin{tabular}{|c|c|}
\hline $\begin{array}{l}\text { Mean inclusion count of } \\
3 \text { coverslips } 48 \mathrm{~h} \\
\text { post-infection }\end{array}$ & $P$ value \\
\hline $\left.\begin{array}{r}4102 \\
2091 \\
3615 \\
0\end{array}\right\}$ & $\begin{array}{l}0.01>P>0.001 \\
P<0.001\end{array}$ \\
\hline $\left.\begin{array}{l}3938 \\
2023\end{array}\right\}$ & $0.01>P>0.001$ \\
\hline $\begin{array}{l}3904 \\
1100\end{array}$ & $P<0.001$ \\
\hline
\end{tabular}

Liverpool-Waymouth medium or in balanced salt solution supplemented with the macromolecular fraction of serum were not significantly lower than in either medium supplemented with $10 \%(\mathrm{v} / \mathrm{v})$ whole serum; the size and quality of inclusions was similar in all cases. However, in Liverpool-Waymouth medium supplemented with serum filtrate there was a marked reduction in the number of inclusions, and in their size and quality, to a level no better than in unsupplemented Liverpool-Waymouth medium. In balanced salt solution plus serum filtrate the inclusion count, size and quality were markedly less than in balanced salt solution plus the macromolecular fraction of serum.

When McCoy cells were seeded directly into Liverpool-Waymouth medium supplemented with $10 \%(\mathrm{v} / \mathrm{v})$ whole serum or one of its two fractions, the average inclusion counts $48 \mathrm{~h}$ after infection in the presence of whole serum and of the macromolecular fraction were similar, i.e. 3645 and 3740 , respectively, but in the presence of serum filtrate the inclusion count was significantly less $(0.01>P>0.001)$, being only 1820 . Furthermore, in the latter case the inclusions were very small and poor in quality and the integrity of the cell monolayer was adversely affected with many elongated and pyknotic cells.

\section{Effect of foetal calf serum on adsorption of chlamydiae}

When adsorption of strain BK with centrifugation took place in Liverpool-Waymouth medium, there was no significant reduction in infectivity when serum was omitted, the inclusion counts being 4867 and 4122 , respectively. In balanced salt solution with $10 \%(\mathrm{v} / \mathrm{v})$ serum, adsorption was as efficient as in Liverpool-Waymouth medium, and the inclusion count was 4486 . However, the adsorption or subsequent infectivity of strain BK centrifuged on to McCoy cells in serum-free balanced salt solution was markedly reduced; only 2460 inclusions were obtained, although the McCoy cell morphology did not seem to be affected by this temporary transfer to non-nutrient medium.

\section{Effect of addition of foetal calf serum at different stages}

Inclusion counts were similar whether serum was present throughout adsorption and infection, or was not added until 5 or even $22 \mathrm{~h}$ after adsorption (Table 3 ). When the addition of serum was delayed for $30 \mathrm{~h}$, i.e. was present only for the last $18 \mathrm{~h}$ of incubation, the inclusion count was slightly reduced but was significantly higher than in cultures where no serum was present at any stage of the infection.

When serum was withdrawn at various intervals after adsorption, even after the first $5 \mathrm{~h}$ of infection, the final count remained significantly higher than in MCC without serum at any time, and not significantly different from counts in MCC where serum was present for the whole $48 \mathrm{~h}$ period. Serum removal, unlike serum addition during infection, necessitated 
Table 3. Effect of adding or withdrawing foetal calf serum from Liverpool-Waymouth medium at various times after infection of McCoy monolayer coverslip cultures with C. trachomatis strain BK on the subsequent inclusion count

$\begin{array}{lcc}\text { Manipulation of serum } & \begin{array}{c}\text { Time of manipulation } \\ \text { after infection }(\mathrm{h})\end{array} & \begin{array}{c}\text { Inclusion count } \mathbf{4 8 ~ h} \\ \text { post-infection }\end{array} \\ \text { Present throughout infection } & - & 4754 \\ \text { Added after infection } & 5 & 4046 \\ & 22 & 4004 \\ \text { Withdrawn after infection } & 30 & 3166 \\ & 5 & 5491 \\ \text { Not present at any stage } & 22 & 5009 \\ & 30 & 4675 \\ & - & 2472\end{array}$

Table 4. Infective yields of C. trachomatis strain BK in McCoy monolayer coverslip cultures (MCC) maintained in Liverpool-Waymouth medium with various supplements

\begin{tabular}{|c|c|c|c|c|}
\hline \multicolumn{5}{|c|}{ Inclusion count in primary $\mathrm{MCC}$} \\
\hline Supplement* & $\begin{array}{c}48 \mathrm{~h} \\
\text { post-infection }\end{array}$ & $\begin{array}{c}72 \mathrm{~h} \\
\text { post-infection }\end{array}$ & $\begin{array}{l}\text { Yield per MCC } \mathrm{MCC}^{\text {(i.f.u.) }}\end{array}$ & $\begin{array}{c}\text { Relative } \\
\text { yield }\end{array}$ \\
\hline Whole serum & 7660 & 5406 & $1.5 \times 10^{5}$ & 1.00 \\
\hline Serum macromolecular fraction & 7956 & 4760 & $1.5 \times 10^{5}$ & $1 \cdot 00$ \\
\hline Serum filtrate & 3148 & 1428 & $2.1 \times 10^{4}$ & 0.14 \\
\hline BSA/oleate/fetuin & 6580 & 4488 & $1.4 \times 10^{5}$ & 0.93 \\
\hline None & 2958 & 1323 & $6.8 \times 10^{4}$ & 0.45 \\
\hline
\end{tabular}

renewal of the Liverpool-Waymouth medium in the culture and this was responsible for a slight but consistent increase in all the inclusion counts (Table 3 ).

\section{Substitution of foetal calf serum by bovine serum albumin, sodium oleate and fetuin}

The mean inclusion count in Liverpool-Waymouth medium containing bovine serum albumin, sodium oleate and fetuin (5075) was $86 \%$ of that in Liverpool-Waymouth medium containing $10 \%(\mathrm{v} / \mathrm{v})$ foetal calf serum (5937). In Liverpool-Waymouth medium with bovine serum albumin alone the mean inclusion count was 3837 ; with sodium oleate alone, 1894; with fetuin alone, 3302; and in Liverpool-Waymouth medium alone, 2307. There was no difference in the appearance of the cell monolayers in the presence of the various serum substitutes, apart from slight elongation of some cells. Inclusion size and quality was best when all three serum substitutes were present together.

\section{Passage of $C$. trachomatis in Liverpool-Waymouth medium supplemented with whole or fractionated foetal calf serum or serum substitutes}

In all media, the inclusion counts fell markedly between 48 and $72 \mathrm{~h}$ incubation of the primary culture (Table 4). This was due to the maturation and rupture of many primary inclusions over this period, thus releasing elementary bodies into the medium. The total yield of inclusion-forming units (i.f.u.) from the primary culture was not decreased by substituting the macromolecular fraction of foetal calf serum or bovine serum albumin/oleate/fetuin 
mixture instead of $10 \%(\mathrm{v} / \mathrm{v})$ foetal calf serum. However, in Liverpool-Waymouth medium with only the serum filtrate fraction or in the medium alone, the i.f.u. yield was greatly reduced.

\section{DISCUSSION}

From the present experiments, it appears that foetal calf serum cannot be omitted from the maintenance medium of McCoy cell cultures without adversely affecting the number, size and quality of the inclusions of $C$. trachomatis strain BK. In fact, the concentration of serum normally added to medium (i.e. $10 \%, \mathrm{v} / \mathrm{v}$ ) appeared to be optimal, and decreasing the concentration gave a progressive decrease in the inclusion count. Foetal calf serum was not essential for adsorption of the BK strain of $C$. trachomatis in Liverpool-Waymouth medium, and even in Earle's balanced salt solution adsorption was reduced but not abolished in the absence of serum. However, adsorption was not improved by removing serum, although it is known that only a fraction of the total number of infective particles in the inoculum normally achieve adsorption from serum-containing media after centrifugation at $3500 \mathrm{~g}$ for $1 \mathrm{~h}$ (Johnson \& Hobson, 1976). After adsorption, withdrawal of serum as early as $5 \mathrm{~h}$ after infection had only a slight effect on the inclusion count. Conversely, when serum was not added until $22 \mathrm{~h}$ after infection, inclusion counts were greater than when serum was absent throughout. Thus, the enhancing effect of serum on chlamydial growth is not confined to a narrow early stage of the growth cycle. It may be a relatively non-specific and indirect physical effect rather than a chemical effect, possibly by stabilizing the host cells in such a way as to allow the continued transport and utilization of nutrients mainly or entirely derived from the Liverpool-Waymouth medium. This view is supported by the observation that the growth of strain BK was not adversely affected in McCoy cells maintained in LiverpoolWaymouth medium plus the macromolecular fraction of serum (from which amino acids were removed), whereas when the serum filtrate was used inclusion counts were markedly decreased. Similarly, in Earle's balanced salt solution alone, supplementation with $10 \%(\mathrm{v} / \mathrm{v})$ serum or its macromolecular fraction allowed normal chlamydial growth, whereas the inclusion count fell markedly when the serum filtrate was used instead.

The total concentration of amino acids, vitamins and hormones in foetal calf serum is considerably lower than in Liverpool-Waymouth medium and other tissue culture medium formulations (Bittles, 1974) and hence it is unlikely that the good growth of strain BK in balanced salt solution supplemented with serum or, especially, with the macromolecular fraction can be attributed simply to the provision of essential nutrients. Since the McCoy cells had not been starved before changing from Liverpool-Waymouth to balanced salt media at the time of infection, the host cells may well have contained sufficient intracellular stores of nutrients for both their own subsequent maintenance and the growth of the chlamydiae within them and been able to utilize these provided that physico-chemical conditions were not disturbed by removing the macromolecular fraction of serum. It may also be feasible to mimic the physico-chemical activity of this fraction, for supplementation of medium with a mixture of bovine serum albumin, sodium oleate and fetuin, in amounts equivalent to their concentration in foetal calf serum, allowed maintenance of apparently normal McCoy cells capable of growing $C$. trachomatis to the inclusion count normally reached in media with $10 \%(\mathrm{v} / \mathrm{v})$ foetal calf serum. However, under these conditions, the progeny particles within these inclusions might be defective, e.g. in cell wall development, and thus reduce their infectivity. Nevertheless, the total yield of strain BK from MCC incubated in media with the macromolecular fraction of serum or with serum substitute was as great as that when $10 \%$ (v/v) whole serum was used, whereas the yield on passage from MCC incubated without serum, or with serum filtrate only, was reduced.

Overall, these experiments suggest that it is possible to omit foetal calf serum from the medium of MCC used in the propagation of genital strains of $C$. trachomatis, and to substitute only its macromolecular components in a form that could be assayed, standardized 
and even mimicked artifically, and thus construct a completely chemically defined medium which will give satisfactory results in terms of both the plating efficiency of the primary infection and in the yield of progeny particles on harvest and subsequent passage. These findings should be of practical value in further attempts to define the exact nutritional requirements for the growth of this important pathogen, and for the investigation of biological differences between the serologically and epidemiologically distinct trachoma, genital and lymphogranuloma venereum strains of $C$. trachomatis, and between these and the various animal pathogens collectively known as $C$. psittaci.

We are grateful to the Medical Research Council for support by a project grant during this work.

\section{REFERENCES}

Alexander, J. J. (1968). Separation of protein synthesis in meningo-pneumonitis agent from that of L-cells by differential susceptibility to cycloheximide. Journal of Bacteriology 95, 327-342.

BADER, J. P. \& Morgan, H. R. (1958). Latent virus infection of cells in tissue culture VI. Role of amino-acids, glutamine and glucose in psittacosis virus propagation in L-cells. Journal of Experimental Medicine 108, 617-620.

BECKER, Y. (1978). The chlamydia: molecular biology of prokaryotic obligate parasites of eukaryocytes. Microbiological Reviews 42, 274-306.

Bittles, A. H. (1974). The comparative analysis of three batches of foetal bovine serum used in tissue culture. Medical Laboratory Technology 31, 253255.

Bushell, A. C. \& Hobson, D. (1978). Effect of cortisol on the growth of Chlamydia trachomatis in McCoy cells. Infection and Immunity 21, 946-953.

Davies, J A., ReEs, E., Hobson, D. \& Karayiannis, P. (1978). Isolation of Chlamydia trachomatis from Bartholin's ducts. British Journal of Venereal Diseases 54, 409-413.

Fisher, H. W., Puck, T. T. \& Sato, G. (1958). Molecular growth requirements of single mammalian cells: the action of fetuin in promoting cell attachment to glass. Proceedings of the National Academy of Sciences of the United States of America 44, 4-10.

Gordon, F. B. \& QuAN, A. L. (1965). Isolation of the trachoma agent in cell culture. Proceedings of the Society for Experimental Biology and Medicine 118, 354-359.

Gordon, F. B., Dressler, H. R., QuaN, A. L., McQullkin, W. T. \& Thomas, J. I. (1972). Effect of ionizing irradiation on susceptibility of McCoy cultures to Chlamydia trachomatis. Applied Microbiology 23, 123-129.

НатсH, T. P. (1975). Competition between C. psittaci and L-cells for isoleucine pools. A limiting factor in chlamydial multiplication. Infection and Immunity 12, 211-220.

HoBSoN, D. (1977a). Non-gonococcal urethritis and related oculo-genital infections. Proceedings of the Royal Society of Medicine 70, 49-52.
Hoвson, D. (1977b). Tissue culture procedures for the isolation of Chlamydia trachomatis from patients with non-gonococcal genital infections. In NonGonococcal Urethritis and Related Infections, pp. 286-294. Edited by D. Hobson \& K. K. Holmes. Washington, D.C.: American Society for Microbiology.

Johnson, F. W. A. \& HoBson, D. (1976). Factors affecting the sensitivity of replicating McCoy cells in the isolation and growth of chlamydia A (TRIC agents). Journal of Hygiene 76, 441-451.

Johnson, F. W. A., Hobson, D., Rees, E. \& TAIT, I. A. (1977). Quantitative aspects of the growth of Chlamydia trachomatis in diagnostic tissue culture procedures. In Non-Gonococcal Urethritis and Related Infections, pp. 309-313. Edited by D. Hobson \& K. K. Holmes. Washington, D.C.: American Society for Microbiology.

Morrison, S. J. \& Jenkin, H. M. (1972). Growth of Chlamydia psittaci strain meningo-pneumonitis in mouse L-cells cultivated in a defined medium in spinner cultures. In vitro 8, 94-100.

RIPA, K. T. \& MÅRDH, P.-A. (1977). Cultivation of Chlamydia trachomatis in cycloheximide-treated McCoy cells. Journal of Clinical Microbiology 6, 328-331.

RotA, T. R. \& Nichols, R. L. (1973). Chlamydia trachomatis in cell culture. Applied Microbiology 26, $560-565$.

Sompolinsky, D. \& Richmond, S. J. (1974). Growth of Chlamydia trachomatis in McCoy cells treated with Cytochalasin B. Applied Microbiology 28, 912-914.

TAYLOR, W. G. (1974). 'Feeding the baby' - serum and other supplements to chemically defined medium. Journal of the National Cancer Institute 53, 1448-1457.

WAYMOUTH, C. (1959). Rapid proliferation of sublines of NCTC clone 929 (strain L) mouse cells in a simple chemically defined medium MB752/1. Journal of the National Cancer Institute 22, 10031017.

Wentworth, B. B. \& Alexander, E. R. (1974). Isolation of Chlamydia trachomatis by use of 5-iodo-2-deoxyuridine-treated cells. Applied Microbiology 27, 912-916. 